\title{
Effect of Post Harvest Treatments and Storage Conditions on Physico-Chemical Properties of Starking Delicious Apples
}

\author{
Neelam Kumari ${ }^{1 *}$ and J.N. Sharma ${ }^{2}$ \\ ${ }^{1}$ Krishi Vigyan Kendra Rohru, Shimla, H.P. (171 207), India \\ ${ }^{2}$ Department of Plant Pathology, Dr. Y. S. Parmar University of Horticulture \\ and Forestry, Nauni, Solan, H.P. (173 230), India \\ *Corresponding author
}

\section{A B S T R A C T}

Keywords

Apple, Botanical formulation, $\mathrm{CA}$ storage, Physicchemical, Precooling, Refrigerated storage

Article Info

Accepted:

17 March 2019

Available Online:

10 April 2019
Freshly harvested apple fruits of cultivar Starking Delicious were subjected to different treatment combinations. Then, the fruits were stored under ambient conditions, refrigerated storage and controlled atmosphere (CA) storage for six months and further analyzed for physico-chemical parameters such as fruit firmness, total soluble solids, titratable acidity, total sugars and total phenols. Among different treatment combinations, hydrocooling of harvested fruits with ice water $+\mathrm{CaCl}_{2}$ along with dipping in $B$. subtilis inoculum, using neem oil (1\%) as surface coating and then placing them on botanical formulation (BF) impregnated fruit trays (treatment combination T7) prior to storage was most effective in retaining better physico-chemical characteristics. Among three different types of storages, CA storage was most effective in retaining physico-chemical parameters of variously treated fruits.

\section{Introduction}

Apple (Malus $\times$ domestica Borkh.) belongs to Rosaceae family and is one of the most economically important fruit trees of temperate zones (Martinelli et al., 2008). Agro-climatic conditions in hilly regions of Himachal Pradesh offer immense natural potential for increasing productivity under temperate fruits, especially apple. Though the area and production under apple cultivation in Himachal Pradesh has increased during the last few decades, but the productivity per unit area has not increased proportionally and is quite low as compared to other apple growing countries of the world. The reasons for low apple productivity could be many, but one of them is lack of sufficient storage infrastructures. Due to its tendency towards fast ripening and quality breakdown, apple is difficult to keep well for longer period of time. Number of workers has made attempts to increase the storage life of apples using different strategies at the pre or post harvest 
stages. However, most of the synthetic chemicals being used for post harvest treatments are reported to pose a serious threat to human health and have residual effect, beside being costly, therefore, all these factors have led to research for other safer and more effective alternatives. However, it has been reported that various botanical extracts such as neem leaf extracts, neem kernel oil, mentha leaf extracts, onion extracts etc. are residue free and safe from consumption point of view as compared to fungicides that are highly toxic to humans and environment. These extracts contain active ingredients that help in reducing decay losses in fruits that are caused by various fungi (Bhowmick and Choudhary 1992). Kleeberg (1996); Deshmukh et al., (1992) have reported that azadirachtin, camacin, menthol and euglone were the active compounds present in neem, melia, mentha and walnut leaves causing strengthening of pectin molecule by eliminating the chances of methyl group removal from the alpha-galactouronic acid residue of pectin; thereby, helping in lowering the breakdown of pectin during storage. Precooling of harvested fruits also facilitates the good temperature management for prevention of ripening and that the onset of senescence is effectively delayed by maintaining low product temperature helping in reducing moisture loss (Kaynas and Sivritepe 1995). Therefore, the present investigation was conducted to determine the effect of integrated treatments such as combination of pre-cooling with natural plant extracts, fumigation and fruit skin coatings to enhance the storage quality of apple cv. Starking Delicious under ambient, refrigerated and CA storage.

\section{Materials and Methods}

\section{Fruits}

Starking Delicious apples were harvested in the months of July and August from a commercial orchard in Shimla district of Himachal Pradesh. The climacteric rise in carbon dioxide production had not yet started.

\section{Treatments}

Apple fruits were subjected to different treatments as described below prior to storage:

T1. HIWC $+\mathrm{HWT}\left(50^{\circ} \mathrm{C}\right)$

T2. T1 + Plant extract

T3. T1 + Antagonist

T4. T1 + SOPP $(1 \%)$

T5. SOPP $(1 \%)+1-M C P$ fumigation

T6. Skin coating with neem oil $(1 \%)+\mathrm{BF}-$ impregnated trays

T7. HIWC + Antagonist + Skin coating with neem oil $(1 \%)+$ BF-impregnated trays

T8. HIWC + Skin coating with neem oil $(1 \%)$ + BF- impregnated trays

T9. Apples untreated + BF-impregnated trays T10. Control (Untreated)

The experiment was laid out in a randomized complete block design taking into account three factors including post harvest treatment, storage type and storage duration.

\section{Hydrocooling with ice water and $\mathrm{CaCl}_{2}$ (HIWC)}

Healthy apple fruits were harvested early morning during the months of July and August. To see the effect of pre-cooling on post harvest rotting of apples, harvested fruits were subjected to hydrocooling with ice water $+\mathrm{CaCl}_{2}(2 \% \mathrm{w} / \mathrm{w})$ for $30 \mathrm{~min}$.

\section{Hot water treatment (HWT)}

Hot water dip treatments were performed in a thermostatically controlled water bath.

Apples were subjected to hot water treatment at $50^{\circ} \mathrm{C}$ for 3 minutes and then moved to storage. 


\section{Plant extract}

Plant extract used was of amla (Emblica officinalis) leaves prepared by using sterilized distilled water. Apples were subjected to dipping in E. officinalis extract at 10 per cent concentration for $5 \mathrm{~min}$ and then moved to storage.

\section{Antagonist}

The antagonist used was the bacterium Bacillus subtilis isolated from neglected apple orchards with minimal or no pesticide spray history.

Apples were subjected to $B$. subtilis inoculum. The inoculum was prepared and adjusted to the concentration of $10^{8} \mathrm{cfu} / \mathrm{ml}$ with the help of spectrophotometer.

\section{1-MCP fumigation}

Apple fruits were kept over a wire gauge in a desiccator and exposed to 1-MCP treatment in the form of pellets $(1 \mu \mathrm{l} / \mathrm{L})$ for 12 hours. Following 1-MCP treatment and before storage, apples were placed on fruit trays and air equilibrated for 6 hours to allow removal of $1-\mathrm{MCP}$ from the fruits.

\section{Skin coating}

Essential oil of neem (Azadirachta indica) at 1 per cent concentration was used as skin coating on apple fruits. The emulsifier (Tween 20) was added to enhance the solubility of oil suspension.

\section{Sodium ortho-phenylphenate (SOPP)}

Apple fruits with uniform size, shape, maturity and free from any defects were dipped in sodium ortho-phenylphenate (SOPP) at 1 per cent concentration for 5 minutes prior to storage.

\section{Impregnation of fruit trays}

Botanical Formulation (BF) was prepared by adding equal quantity of the sterilized plant extract of five plants [Murraya exotica (Gandla), Dodonaea viscosa (Mehandu), Mentha piperita (Pudina), Emblica officinalis (Amla) and Melia azadirach (Darek)] to equal quantity of sterilized distilled water (w/v). Impregnation of fruit trays was done by spraying BF (10 \%) over 10 fruit trays followed by shade drying. Apples were placed in BF-impregnated fruit trays and then moved to storage.

\section{Fruit storage}

Both treated and untreated fruits were stored at ambient conditions $\left(20 \pm 2^{\circ} \mathrm{C}\right)$, refrigerated storage $\left(4^{\circ} \mathrm{C}\right)$ and controlled atmosphere $(\mathrm{CA})$ $\left(1 \pm 0.5^{\circ} \mathrm{C}\right.$ temperature, 87 to $92 \% \mathrm{RH}, 1.4 \%$ carbon dioxide and $1.2 \%$ oxygen concentration) storage for six months and evaluated for physico-chemical parameters.

\section{Physico-chemical parameters}

Fruit physico-chemical parameters in terms of firmness, total soluble solids (TSS), titratable acidity, total sugars and total phenols were assayed both from treated and untreated fruits during six months of storage.

\section{Fruit firmness}

The firmness of apple fruits was estimated with the help of a penetrometer. The skin of the fruits was removed using slicers to about $1 \mathrm{~mm}$ depth and flesh firmness was then measured with a penetrometer equipped with $11 \mathrm{~mm}$ diameter plunger tip. The observations were recorded in lbs/sq.inch.

\section{Total soluble solids (TSS)}

The total soluble solids (TSS) content of the fruit samples was determined with the help of 
a hand refractometer. A drop of the juice squeezed from fruit samples was placed on the prism of refractometer and viewed through the eye piece and expressed as ${ }^{\circ}$ Brix. Five fruits were taken from each treatment for recording this observation.

\section{Titratable acidity}

Twenty five gram of fruit pulp was thoroughly homogenized with distilled water in a waring blender and the volume was made upto $250 \mathrm{ml}$. Then, the homogenized mixture was filtered through Whatman No.1 filter paper. Then $10 \mathrm{ml}$ sample from the filtrate was titrated against $0.1 \mathrm{~N} \mathrm{NaOH}$ solution using phenolphthalein as indicator in each treatment. The end point was noted with change in colour to pink. The total titratable acidity was calculated in terms of malic acid (1 $\mathrm{ml}$ of $0.1 \mathrm{~N} \mathrm{NaOH}$ being equivalent to $0.0067 \mathrm{~g}$ anhydrous malic acid). The results were expressed as per cent flesh weight of fruit pulp.

Titratable acidity $(\%)=$

Titre XNormality of $\mathrm{NaOH} \times$ Volume made X Equivalent weight of acid X 100

Volume of sample taken $X$ Weight orvolume of aliquottaken $X 1000$

\section{Total sugars}

The sugar content of the fruit was determined by volumetric method based on the principle that sucrose content of fruit is quantitatively hydrolyzed to glucose and fructose in the presence of $\mathrm{HCl}$ as per the method suggested by A.O.A.C. (1960). The remnant of the 200 $\mathrm{ml}$ extract left from titratable acidity was taken in a $250 \mathrm{ml}$ volumetric flask and $5 \mathrm{ml}$ of 10 per cent lead acetate was added. After 5-10 minutes, $5 \mathrm{ml}$ of 10 per cent sodium oxalate was added to precipitate the excess of lead acetate and volume was made $250 \mathrm{ml}$ followed by the filtration of the solution. Thereafter, $50 \mathrm{ml}$ of the filtrate was taken and hydrolyzed by adding concentrated $\mathrm{HCl}$. The solution was allowed to stand overnight for the reaction to be completed. The next day, the excess of $\mathrm{HCl}$ in the solution was neutralized with standard $\mathrm{NaOH}$ solution.

The hydrolyzed aliquot was then taken in a burette and titrated against boiling solution containing $5 \mathrm{ml}$ each of Fehling $\mathrm{A}$ and Fehling B. Methylene blue was used as indicator and the end point was indicated by the appearance of brick red colour. The total sugar was expressed as per cent of fresh weight of the fruit pulp.

Total sugars $(\%)=$

$\frac{\text { Dye factor } \times \text { Dilution }}{\text { Titre value } \times \text { Weight orvolume of sample taken }} \times$
100

\section{Total phenols}

Apple fruits (flesh + peel) were cut with a knife, put in boiling alcohol in a water bath for 5-10 minutes (4 $\mathrm{ml}$ alcohol/gm tissue). After 15 minutes of boiling, it was cooled and crushed in mortar and pestle thoroughly at room temperature. The extract was passed through double layer of cheese cloth and then filtered through Whatman No. 1 filter paper. Final volume was adjusted with 80 per cent ethanol. The whole experiment was performed in dark to prevent light induced degradation of phenols. Total phenols were estimated by the method described by Bray and Thorpe (1954).

\section{Reagents}

Folin-Ciocalteu Reagent (FCR)

$80 \%$ Ethanol

$20 \%$ Sodium carbonate

\section{Procedure}

To one ml of alcohol extract, one ml of FolinCiocalteu reagent was added followed by the 
addition of $2 \mathrm{ml}$ of 20 per cent sodium carbonate solution. The contents were shaken before heating in a boiling water bath for exactly one minute and then cooled in running tap water. The blue solution so obtained was diluted to $25 \mathrm{ml}$ with double distilled water. After half an hour optical density of the solution was read at $650 \mathrm{~nm}$. A blank containing all the reagents minus FolinCiocalteu reagent was used to adjust the absorbance to zero. Total phenols were calculated from the standard curve prepared from caffeic acid.

\section{Results and Discussion}

\section{Physico-chemical parameters}

\section{Fruit firmness (lbs/sq.inch)}

Fruit firmness decreased under all treatments as the storage period progressed (Table 1). Among different treatments, maximum mean firmness (13.68 lbs/sq.inch) was recorded in T7 followed by T8 (13.19 lbs/sq.inch) and T6 (11.04 lbs/sq.inch), possibly due to reduction of both rate of metabolism and water loss (Singh and Chauhan, 1986; Bhardwaj and Sen, 2003). T5 with mean fruit firmness of $9.33 \mathrm{lbs} / \mathrm{sq}$.inch was significantly at par with T2 (8.36 lbs/sq.inch) and T3 (7.78 lbs/sq.inch), respectively. Minimum fruit firmness (5.63 lbs/sq.inch) was observed in fruits treated with $\mathrm{T} 1$ followed by $\mathrm{T} 9$ (6.10 lbs/sq.inch). These findings are in close conformity with the findings of Rombaldi et al., (2001) in peaches and Changhoo et al., (2001) in Kiwi fruits.

The interaction studies between treatments, storage type and storage duration revealed that irrespective of the treatments minimum fruit firmness (6.48 lbs/sq.inch) was recorded in fruits stored in ambient storage whereas maximum (11.03 lbs/sq.inch) was recorded in fruits stored in CA storage. Refrigerated storage (RS) was the next best storage type with mean fruit firmness of $8.0 \mathrm{lbs} / \mathrm{sq}$.inch. Fruit firmness decreased as the storage duration extends from 3 to 6 months. The interaction between treatments, storage type and storage duration was found to be nonsignificant. Research works on other apple cultivars have demonstrated that CA storage is effective to delay the loss of fruit firmness (Erkan et al., 2004; Jinhe et al., 2005; Levesque et al., 2006). It has been previously reported that calcium treatments of harvested fruits resulted in slower fruit softening during storage (Duque et al., 1999; Valero et al., 2002). Raj and Tomar (2013) reported that dipping of fruits in botanical formulation prepared in cow urine was equally effective in retaining firmness of fruits during storage.

\section{Total soluble solids ( ${ }^{\circ}$ Brix)}

Total soluble solids (TSS) content of the harvested fruits have been reported to increase during storage (Riveria, 2005). The data presented in Table 2 indicated that TSS content of the fruits increased with the advancement of storage period. Such increase in TSS content is expected to be slower and more gradual when metabolism of the harvested commodity is slowed down by the application of treatments viz. pre-cooling, skin coating, impregnation of fruit trays etc. After 6 months of storage, treatment T7 had minimum TSS of $9.22^{\circ}$ Brix followed by T8 $\left(9.41^{\circ}\right.$ Brix $)$ and T6 $\left(9.53{ }^{\circ}\right.$ Brix $)$. Treatments T5, T2 and T3 were significantly at par with each other with overall TSS content of 9.66, 9.77 and $9.96{ }^{\circ}$ Brix, respectively. Maximum TSS content $\left(10.83{ }^{\circ}\right.$ Brix $)$ was recorded in fruits treated with $\mathrm{T} 1$ followed by $\mathrm{T} 9$ (10.50 ${ }^{\circ}$ Brix). These findings are further supported by the observations of Singh and Mohammed (1997).

The interaction studies between treatments, storage type and storage duration revealed 
that irrespective of the treatments, maximum TSS content $\left(10.94{ }^{\circ}\right.$ Brix $)$ was recorded in fruits stored in ambient storage, whereas minimum TSS content $\left(9.39^{\circ}\right.$ Brix $)$ was recorded in fruits stored in $\mathrm{CA}$ storage. Refrigerated storage (RS) was the next best storage type with mean fruit TSS content of $9.81{ }^{\circ}$ Brix. TSS content of fruit increased as the storage duration extends from 3 to 6 months. The interaction between treatments, storage type and storage duration was found to be non-significant.

Tzortzakis (2007) reported that treatment of strawberry fruits with cinnamon (Cinnamomum zeylanicum) and eucalyptus (Eucalyptus globulus) vapours resulted into increase in fruit TSS during storage. Skin coating of apple fruits with neem oil has been reported to provide better retention of physico-chemical characteristics of fruits including firmness, total soluble solids, and titratable acidity of fruit (Chauhan et al., 2008; Wijewardane and Guleria 2009).

\section{Titratable acidity (\% Malic acid)}

Data regarding the effect of integrated management on titratable acidity (\% Malic acid) of Starking Delicious apples during different types of storage for 6 months has been presented in Table 3 and the perusal of data revealed that maximum titratable acidity $(0.26 \%)$ was observed in fruits treated with T7 followed by T8 $(0.25 \%)$ and T6 $(0.23 \%)$. The next best treatment in the order of merit was T5 $(0.21 \%)$ which was statistically at par with T2 (0.20\%) and T3 (0.19\%), respectively. Minimum titratable acidity $(0.14 \%)$ was recorded in fruits treated with $\mathrm{T} 1$ followed by T9 $(0.17 \%)$. The faster rate of decline in acidity in control fruits $(0.08 \%)$ could be due to the faster metabolic reactions occurring within them during storage. The interaction studies between treatments, storage types and storage duration revealed that maximum titratable acidity $(0.22 \%)$ was recorded in the fruits stored under CA storage followed by refrigerated $(0.21 \%)$ and ambient storage $(0.16 \%)$, respectively. Decrease in titratable acidity was recorded in all types of storage as the storage duration extends from 3 to 6 months; however, this decrease was relatively slow in CA and refrigerated storage. Similar decline in acidity under ambient conditions was also reported by Meena et al., (2009).

Wijewardane and Guleria (2009) also reported maximum titratable acidity $(0.30 \%)$ in apple fruits treated with neem oil. Shinde et al., (2009) also reported that fruit dipping treatment with neem oil (10\%) was highly effective in retaining maximum titratable acidity of mango fruits in storage. Ergun and Satici (2012) reported that higher concentration of Aloe vera gel delayed increase in titratable acidity in Granny Smith variety of apple.

\section{Total sugars (\%)}

Data regarding the effect of integrated management on total sugar content of apple fruits stored under different conditions for 6 months has been presented in Table 4. The perusal of data revealed that overall minimum total sugar content $(7.54 \%)$ was recorded in fruits treated with $\mathrm{T} 7$ followed by $\mathrm{T} 8(7.72 \%)$ and T6 $(7.80 \%)$. The next best treatment in the order of merit was T5 with total sugar content of 7.96 per cent which was statistically at par with treatment T2 $(8.13 \%)$ and T3 $(8.25 \%)$, respectively. Maximum total sugar content $(8.65 \%)$ was observed in $\mathrm{T} 1$ followed by T9 $(8.53 \%)$. Similar changes in sugar content of fruits were also reported by Prashant and Masoodi (2009).

The interaction studies between treatments, storage types and storage duration revealed that minimum total sugar content $(7.42 \%)$ was 
observed in fruits stored in CA storage whereas maximum total sugars $(9.54 \%)$ was recorded in fruits stored under ambient storage. The increase in sugar content may be due to the hydrolysis of insoluble polysaccharides into simple sugars and also increased concentration of organic solutes as a consequence of moisture loss.

The next best storage type was refrigerated storage with mean total sugar content of 8.02 per cent. A certain level of increase of total sugar content was typical during 3 months of storage with a subsequent decrease thereafter. The decrease was more rapid in ambient storage as compared to in refrigerated and CA storage. The interaction between treatments, storage types and storage duration was found to be non-significant.

Reducing sugar content of the control fruits was maximum $(6.9 \%)$ after 3 weeks of storage whereas, fruits treated with 6 per cent $\mathrm{CaCl}_{2}$ recorded the minimum reducing sugar content (6.6\%). $\quad \mathrm{CaCl}_{2}$ treatment caused inactivation of hydrolyzing enzymes responsible for conversion of starch into sugars (Gupta et al., 2011).

\section{Total Phenols (mg/kg of fresh weight)}

Data presented in Table 5 regarding the effect of integrated management on total phenolic content of apple fruits stored for 6 months under different storage conditions revealed that maximum total phenol content (697.50 $\mathrm{mg} / \mathrm{kg}$ ) was recorded in the fruits treated with T7 followed by $\mathrm{T} 8(693.71 \mathrm{mg} / \mathrm{kg})$ and $\mathrm{T} 6$ $(691.67 \mathrm{mg} / \mathrm{kg})$. The next best treatment was T5 with total sugar content of $689.17 \mathrm{mg} / \mathrm{kg}$ which was statistically at par with T2 (682.90 $\mathrm{mg} / \mathrm{kg}$ ) and T3 (679.70 mg/kg), respectively. Minimum total sugar content $(655.68 \mathrm{mg} / \mathrm{kg})$ was observed in fruits treated with $\mathrm{T} 1$ followed by T9 (664.74 $\mathrm{mg} / \mathrm{kg})$. The interaction studies between treatments, storage types and storage duration revealed that maximum total phenols content $(818.86$ $\mathrm{mg} / \mathrm{kg}$ ) was recorded in the fruits stored under CA storage followed by refrigerated (765.08 $\mathrm{mg} / \mathrm{kg}$ ), whereas minimum total phenols $(435.11 \mathrm{mg} / \mathrm{kg})$ was recorded in fruits stored under ambient storage. A typical increase in total phenolic content was noticed in $\mathrm{CA}$ and refrigerated storage as the storage duration extends from 3 to 6 months, however, the increase was slight in refrigerated storage as compared to CA storage.

On the contrary, a sharp decline in total phenolic content was observed in the fruits stored under ambient temperature irrespective of different treatments applied due to greater activity of polyphenol oxidase in fruits stored at ambient temperature that resulted in conversion of polyphenols into brown pigments, hence decreasing the content of phenols in fruits. These results are in conformity with those obtained by Matthes and Schmitz-Eiberger (2009). The interaction between treatments, storage types and storage duration was found to be significant.

An increase of polyphenol content during storage could be due to ethylene action. This phytohormone stimulates the activity of the key enzyme (phenylalanine ammonium lyase) in polyphenol biosynthesis which leads to production of polyphenols (Leja et al., 2001; Napolitano et al., 2004). Tomas-barberan and Espin (2001) reported that PAL activity is higher at lower temperatures.

The present results are different from those reported by Tarrozi et al., (2004) who found lower phenol content in the peel of apple fruits after cold storage for three months, no further effect was seen after six month. Napolitano et al., (2004) reported decrease of antioxidant concentration in a water extract of apple fruits during storage which was related to the ascorbic acid degradation. 
Table.1 Effect of post harvest treatments and storage conditions on fruit firmness of Starking Delicious apples

\begin{tabular}{|c|c|c|c|c|c|c|c|c|c|c|}
\hline \multirow[t]{3}{*}{ Treatment } & \multicolumn{9}{|c|}{ Fruit firmness (lbs/sq.inch) } & \multirow{3}{*}{$\begin{array}{l}\text { Overall } \\
\text { Mean }\end{array}$} \\
\hline & \multicolumn{3}{|c|}{ Ambient storage } & \multicolumn{3}{|c|}{ Refrigerated storage } & \multicolumn{3}{|c|}{ CA storage } & \\
\hline & $\begin{array}{c}3 \\
\text { Months }\end{array}$ & $\begin{array}{c}6 \\
\text { Months }\end{array}$ & Mean & $\begin{array}{c}3 \\
\text { Months }\end{array}$ & $\begin{array}{c}6 \\
\text { Months }\end{array}$ & Mean & $\begin{array}{c}3 \\
\text { Months }\end{array}$ & $\begin{array}{c}6 \\
\text { Months }\end{array}$ & Mean & \\
\hline HIWC + HWT $\left(50^{\circ} \mathrm{C}\right)(\mathrm{T} 1)$ & 4.05 & 3.28 & 3.67 & 5.98 & 4.45 & 5.21 & 8.69 & 7.32 & 8.01 & 5.63 \\
\hline T1 + Plant extract (T2) & 6.60 & 5.87 & 6.24 & 8.89 & 7.33 & 8.11 & 11.96 & 9.48 & 10.72 & 8.36 \\
\hline T1 + Antagonist (T3) & 6.25 & 5.54 & 5.89 & 8.39 & 6.73 & 7.56 & 11.14 & 8.66 & 9.90 & 7.78 \\
\hline $\mathrm{T} 1$ + SOPP (1\%) (T4) & 4.52 & 4.81 & 4.67 & 7.77 & 6.03 & 6.90 & 9.95 & 7.85 & 8.90 & 6.82 \\
\hline $\begin{array}{l}\text { SOPP }(1 \%)+1-M C P \text { fumigation } \\
\text { (T5) }\end{array}$ & 7.58 & 6.24 & 6.91 & 10.11 & 7.87 & 8.99 & 12.45 & 11.73 & 12.09 & 9.33 \\
\hline $\begin{array}{l}\text { Skin coating with neem oil }(1 \%)+ \\
\text { BF- impregnated trays (T6) }\end{array}$ & 8.90 & 7.73 & 8.32 & 12.81 & 9.97 & 11.39 & 14.35 & 12.45 & 13.40 & 11.04 \\
\hline $\begin{array}{l}\text { HIWC + Antagonist + Skin coating } \\
\text { with neem oil }(1 \%)+\text { BF- } \\
\text { impregnated trays (T7) }\end{array}$ & 11.83 & 10.55 & 11.19 & 14.58 & 12.86 & 13.72 & 16.97 & 15.28 & 16.13 & 13.68 \\
\hline $\begin{array}{l}\text { HIWC + Skin coating with neem } \\
\text { oil }(1 \%)+\text { BF-impregnated trays } \\
\text { (T8) }\end{array}$ & 11.36 & 10.24 & 10.80 & 14.12 & 12.38 & 13.25 & 16.46 & 14.58 & 15.52 & 13.19 \\
\hline $\begin{array}{l}\text { Apples untreated } \\
\text { impregnated trays (T9) }\end{array}$ & 3.87 & 3.79 & 3.83 & 7.07 & 5.15 & 6.11 & 9.37 & 7.37 & 8.37 & 6.10 \\
\hline Control (T10) & 4.08 & 2.60 & 3.34 & 5.22 & 4.27 & 4.75 & 7.68 & 6.88 & 7.28 & 5.12 \\
\hline Mean & 6.90 & 6.06 & 6.48 & 9.49 & 7.70 & 8.0 & 11.90 & 10.16 & 11.03 & - \\
\hline
\end{tabular}

$\mathrm{CD}_{(0.05)}$ Treatment $=0.344 ;$ Storage $=0.217$; Treatment $\times$ Storage Type $=0.687$; Storage Duration $=0.154 ;$ Treatment $\times$ Storage Duration $=$ N/A; Storage Type $\times$ Storage Duration $=0.307$; Treatment $\times$ Storage Type $\times$ Storage Duration $=$ N/A 
Table.2 Effect of post harvest treatments and storage conditions on total soluble solids of Starking delicious apples

\begin{tabular}{|c|c|c|c|c|c|c|c|c|c|c|}
\hline \multirow[t]{3}{*}{ Treatment } & \multicolumn{9}{|c|}{ Total soluble solids ( ${ }^{\circ}$ Brix) } & \multirow{3}{*}{$\begin{array}{l}\text { Overall } \\
\text { Mean }\end{array}$} \\
\hline & \multicolumn{3}{|c|}{ Ambient storage } & \multicolumn{3}{|c|}{ Refrigerated storage } & \multicolumn{3}{|c|}{ CA storage } & \\
\hline & $\begin{array}{c}3 \\
\text { Months }\end{array}$ & $\begin{array}{c}6 \\
\text { Months }\end{array}$ & Mean & $\begin{array}{c}3 \\
\text { Months }\end{array}$ & $\begin{array}{c}6 \\
\text { Months }\end{array}$ & Mean & $\begin{array}{c}3 \\
\text { Months }\end{array}$ & $\begin{array}{c}6 \\
\text { Months }\end{array}$ & Mean & \\
\hline HIWC + HWT $\left(50^{\circ} \mathrm{C}\right)(\mathrm{T} 1)$ & 11.24 & 12.28 & 11.76 & 10.37 & 10.84 & 10.61 & 9.95 & 10.29 & 10.12 & 10.83 \\
\hline T1 + Plant extract (T2) & 9.94 & 11.22 & 10.58 & 9.41 & 9.80 & 9.61 & 8.98 & 9.28 & 9.13 & 9.77 \\
\hline T1 + Antagonist (T3) & 10.16 & 11.41 & 10.79 & 9.60 & 10.00 & 9.80 & 9.14 & 9.42 & 9.28 & 9.96 \\
\hline T1 + SOPP (1\%) (T4) & 10.56 & 11.63 & 11.10 & 9.74 & 10.21 & 9.97 & 9.37 & 9.74 & 9.56 & 10.21 \\
\hline $\begin{array}{l}\text { SOPP }(1 \%) \\
\text { fumigation (T5) }\end{array}$ & 9.79 & 11.13 & 10.46 & 9.32 & 9.68 & 9.50 & 8.89 & 9.16 & 9.03 & 9.66 \\
\hline $\begin{array}{l}\text { Skin coating with neem oil (1\%) } \\
+ \text { BF- impregnated trays (T6) }\end{array}$ & 9.65 & 11.00 & 10.33 & 9.15 & 9.55 & 9.35 & 8.81 & 9.00 & 8.91 & 9.53 \\
\hline $\begin{array}{l}\text { HIWC }+ \text { Antagonist }+ \text { Skin } \\
\text { coating with neem oil }(1 \%)+ \\
\text { BF-impregnated trays (T7) }\end{array}$ & 9.33 & 10.64 & 9.99 & 8.79 & 9.32 & 9.06 & 8.56 & 8.68 & 8.62 & 9.22 \\
\hline $\begin{array}{l}\text { HIWC + Skin coating with neem } \\
\text { oil }(1 \%)+\text { BF-impregnated trays } \\
\text { (T8) }\end{array}$ & 9.56 & 10.86 & 10.21 & 8.96 & 9.49 & 9.22 & 8.75 & 8.86 & 8.81 & 9.41 \\
\hline $\begin{array}{l}\text { Apples untreated } \\
\text { impregnated trays (T9) }\end{array}$ & 10.86 & 11.85 & 11.35 & 9.97 & 10.47 & 10.22 & 9.84 & 10.02 & 9.93 & 10.50 \\
\hline Control (T10) & 12.58 & 13.01 & 12.80 & 10.56 & 10.97 & 10.77 & 10.32 & 10.65 & 10.49 & 11.35 \\
\hline Mean & 10.37 & 11.50 & 10.94 & 9.59 & 10.03 & 9.81 & 9.26 & 9.51 & 9.39 & - \\
\hline
\end{tabular}

$\mathrm{CD}_{(0.05)}$ Treatment $=0.188 ;$ Storage $=0.119 ;$ Treatment $\times$ Storage Type $=$ N/A; Storage Duration $=0.084$; Treatment $\times$ Storage Duration $=$ N/A; Storage Type $\times$ Storage Duration $=0.168$; Treatment $\times$ Storage Type $\times$ Storage Duration $=$ N/A 
Table.3 Effect of post harvest treatments and storage conditions on titratable acidity of starking delicious apples

\begin{tabular}{|c|c|c|c|c|c|c|c|c|c|c|}
\hline \multirow[t]{3}{*}{ Treatment } & \multicolumn{9}{|c|}{ Titratable acidity (\% Malic acid) } & \multirow{3}{*}{$\begin{array}{l}\text { Overall } \\
\text { Mean }\end{array}$} \\
\hline & \multicolumn{3}{|c|}{ Ambientstorage } & \multicolumn{3}{|c|}{ Refrigerated storage } & \multicolumn{3}{|c|}{ CA storage } & \\
\hline & $\begin{array}{c}3 \\
\text { Months }\end{array}$ & $\begin{array}{c}6 \\
\text { Months }\end{array}$ & Mean & $\begin{array}{c}3 \\
\text { Months }\end{array}$ & $\begin{array}{c}6 \\
\text { Months }\end{array}$ & Mean & $\begin{array}{c}3 \\
\text { Months }\end{array}$ & $\begin{array}{c}6 \\
\text { Months }\end{array}$ & Mean & \\
\hline HIWC + HWT $\left(50^{\circ} \mathrm{C}\right)(\mathrm{T} 1)$ & 0.13 & 0.10 & 0.11 & 0.15 & 0.13 & 0.14 & 0.17 & 0.16 & 0.17 & 0.14 \\
\hline T1 + Plant extract (T2) & 0.18 & 0.14 & 0.16 & 0.23 & 0.19 & 0.21 & 0.24 & 0.23 & 0.23 & 0.20 \\
\hline T1 + Antagonist (T3) & 0.17 & 0.13 & 0.15 & 0.21 & 0.21 & 0.21 & 0.23 & 0.22 & 0.22 & 0.19 \\
\hline T1 + SOPP (1\%) (T4) & 0.15 & 0.12 & 0.14 & 0.20 & 0.19 & 0.20 & 0.21 & 0.19 & 0.20 & 0.18 \\
\hline $\begin{array}{l}\text { SOPP }(1 \%)+1-M C P \\
\text { fumigation }(\mathrm{T} 5)\end{array}$ & 0.19 & 0.16 & 0.18 & 0.23 & 0.21 & 0.22 & 0.24 & 0.22 & 0.23 & 0.21 \\
\hline $\begin{array}{l}\text { Skin coating with neem oil } \\
(1 \%)+B F-\text { impregnated } \\
\text { trays }(\mathrm{T} 6)\end{array}$ & 0.22 & 0.16 & 0.19 & 0.25 & 0.24 & 0.25 & 0.27 & 0.24 & 0.26 & 0.23 \\
\hline $\begin{array}{l}\text { HIWC + Antagonist + Skin } \\
\text { coating with neem oil (1\%) } \\
+\quad \text { BF-impregnated trays } \\
\text { (T7) }\end{array}$ & 0.25 & 0.20 & 0.23 & 0.29 & 0.27 & 0.28 & 0.30 & 0.27 & 0.28 & 0.26 \\
\hline $\begin{array}{l}\text { HIWC + Skin coating with } \\
\text { neem oil }(1 \%)+\text { BF- } \\
\text { impregnated trays }(\mathrm{T} 8)\end{array}$ & 0.24 & 0.18 & 0.21 & 0.28 & 0.26 & 0.27 & 0.29 & 0.25 & 0.27 & 0.25 \\
\hline $\begin{array}{l}\text { Apples untreated }+ \text { BF- } \\
\text { impregnated trays }(\mathrm{T} 9)\end{array}$ & 0.14 & 0.11 & 0.13 & 0.18 & 0.17 & 0.18 & 0.19 & 0.18 & 0.19 & 0.17 \\
\hline Control (T10) & 0.10 & 0.06 & 0.08 & 0.14 & 0.12 & 0.13 & 0.15 & 0.14 & 0.15 & 0.12 \\
\hline Mean & 0.18 & 0.14 & 0.16 & 0.22 & 0.20 & 0.21 & 0.23 & 0.21 & 0.22 & - \\
\hline
\end{tabular}

$\mathrm{CD}_{(0.05)}$ Treatment $=0.005 ;$ Storage $=0.003$; Treatment $\times$ Storage Type $=0.011 ;$ Storage Duration $=0.002 ;$ Treatment $\times$ Storage Duration $=0.008 ;$ Storage Type $\times$ Storage Duration $=0.005$; Treatment $\times$ Storage Type $\times$ Storage Duration $=0.015$ 
Table.4 Effect of post harvest treatments and storage conditions on total sugars of starking delicious apples

\begin{tabular}{|c|c|c|c|c|c|c|c|c|c|c|}
\hline \multirow[t]{3}{*}{ Treatment } & \multicolumn{9}{|c|}{ Total sugars $(\%)$} & \multirow{3}{*}{$\begin{array}{c}\text { Overall } \\
\text { Mean }\end{array}$} \\
\hline & \multicolumn{3}{|c|}{ Ambient storage } & \multicolumn{3}{|c|}{ Refrigerated storage } & \multicolumn{3}{|c|}{ CA storage } & \\
\hline & $\begin{array}{c}3 \\
\text { Months }\end{array}$ & $\begin{array}{c}6 \\
\text { Months }\end{array}$ & Mean & $\begin{array}{c}3 \\
\text { Months }\end{array}$ & $\begin{array}{c}6 \\
\text { Months }\end{array}$ & Mean & $\begin{array}{c}3 \\
\text { Months }\end{array}$ & $\begin{array}{c}6 \\
\text { Months }\end{array}$ & Mean & \\
\hline HIWC + HWT $\left(50^{\circ} \mathrm{C}\right)(\mathrm{T} 1)$ & 10.11 & 9.11 & 9.61 & 8.62 & 8.20 & 8.41 & 8.24 & 7.62 & 7.93 & 8.65 \\
\hline T1 + Plant extract (T2) & 9.67 & 8.57 & 9.12 & 8.18 & 7.80 & 7.99 & 7.64 & 6.93 & 7.29 & 8.13 \\
\hline T1 + Antagonist (T3) & 9.73 & 8.63 & 9.18 & 8.34 & 7.93 & 8.14 & 7.78 & 7.07 & 7.42 & 8.25 \\
\hline T1 + SOPP (1\%) (T4) & 9.87 & 8.78 & 9.33 & 8.49 & 8.14 & 8.31 & 7.97 & 7.26 & 7.62 & 8.42 \\
\hline $\begin{array}{l}\text { SOPP }(1 \%) \\
\text { fumigation }(\mathrm{T5})\end{array}$ & 9.45 & 8.36 & 8.91 & 7.99 & 7.65 & 7.82 & 7.54 & 6.78 & 7.16 & 7.96 \\
\hline $\begin{array}{l}\text { Skin coating with neem oil }(1 \%) \\
\text { + BF- impregnated trays (T6) }\end{array}$ & 9.30 & 8.15 & 8.73 & 7.86 & 7.53 & 7.69 & 7.41 & 6.57 & 6.99 & 7.80 \\
\hline $\begin{array}{l}\text { HIWC }+ \text { Antagonist }+ \text { Skin } \\
\text { coating with neem oil }(1 \%)+ \\
\text { BF-impregnated trays }(\mathrm{T} 7)\end{array}$ & 9.04 & 7.90 & 8.47 & 7.56 & 7.12 & 7.34 & 7.27 & 6.38 & 6.82 & 7.54 \\
\hline $\begin{array}{l}\text { HIWC + Skin coating with neem } \\
\text { oil }(1 \%)+\text { BF-impregnated trays } \\
\text { (T8) }\end{array}$ & 9.17 & 8.03 & 8.60 & 7.75 & 7.40 & 7.58 & 7.41 & 6.55 & 6.98 & 7.72 \\
\hline $\begin{array}{l}\text { Apples untreated } \\
\text { impregnated trays (T9) }\end{array}$ & 9.96 & 8.91 & 9.44 & 8.54 & 8.25 & 8.40 & 8.10 & 7.39 & 7.74 & 8.53 \\
\hline Control (T10) & 14.90 & 13.12 & 14.01 & 8.75 & 8.36 & 8.55 & 8.53 & 8.01 & 8.27 & 10.28 \\
\hline Mean & 10.12 & 8.96 & 9.54 & 8.21 & 7.84 & 8.02 & 7.79 & 7.06 & 7.42 & - \\
\hline
\end{tabular}

$\mathrm{CD}_{(0.05)}$ Treatment $=0.257$; Storage $=0.162$; Treatment $\times$ Storage Type $=0.514$; Storage Duration $=0.115 ;$ Treatment $\times$ Storage Duration $=$ N/A; Storage Type $\times$ Storage Duration $=0.230$; Treatment $\times$ Storage Type $\times$ Storage Duration $=$ N/A 
Table.5 Effect of post harvest treatments and storage conditions on total phenolic content of starking delicious apples

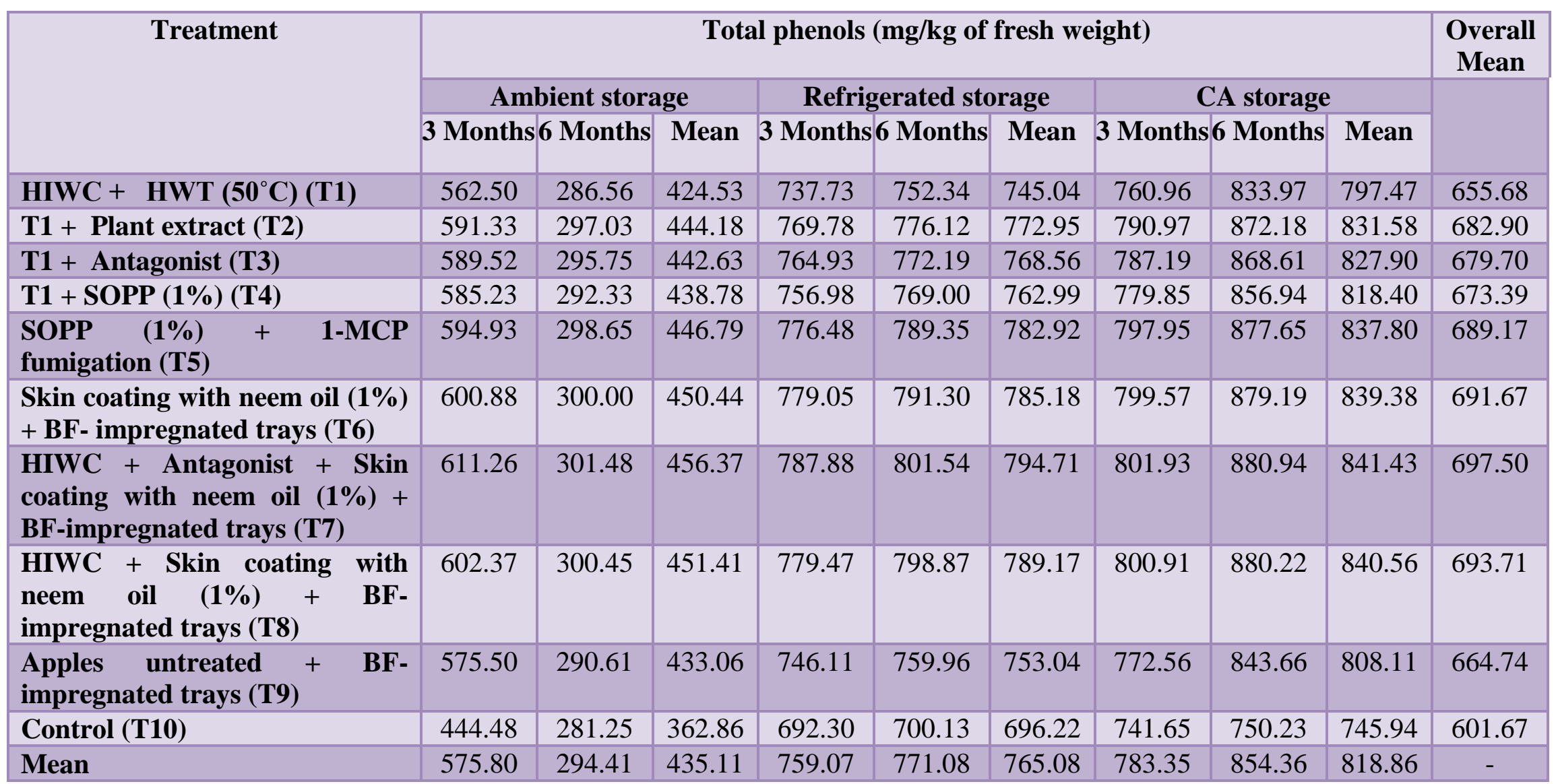

$\mathrm{CD}_{(0.05)}$ Treatment $=1.151 ;$ Storage $=0.72 ;$ Treatment $\times$ Storage Type $=2.301 ;$ Storage Duration $=0.515$; Treatment $\times$ Storage Duration $=1.627$; Storage Type $\times$ Storage Duration $=1.029$; Treatment $\times$ Storage Type $\times$ Storage Duration $=3.254$ 
Awad and De Jager (2000) observed no significant changes in flavonoid content of apple cultivars 'Jonagold' and 'Elstar' upon storage for 30 weeks under $\mathrm{CA}$ and cold conditions. There were no significant differences in flavonoid content of fruits stored under $\mathrm{CA}$ and regular conditions $\left(0^{\circ} \mathrm{C}\right)$. Van Der Sluis et al., (2001) reported that CA and storage in a cold chamber did not influence flavonoid concentration and antioxidant activity of apple fruits. This is consistent with the findings of Golding et al., (2001) who reported no changes in the concentration of the major phenolics during long-term storage. Leja et al., (2001) reported an increase in total phenolic content and a doubling of antioxidant activity after four months of storage in cold chamber and under CA conditions.

In conclusion, the results revealed that 1 per cent concentration of neem oil as a surface coating along with pre-cooling with ice water $+\mathrm{CaCl}_{2}$, dipping of fruits in $B$. subtilis inoculum followed by placing them in BFimpregnated fruit trays was most effective in providing better physic-chemical umbrella. Among three different types of storages, CA storage was most effective in retaining firmness, TSS, titratable acidity, total sugars and total phenolic content of variously treated fruits. Such treatment combinations can be further encouraged for economically important fruits to retain their freshness during storage.

\section{References}

AOAC (1960) Methods of Analysis. 10 ${ }^{\text {th }}$ ed. Association of official agricultural chemists, Washington, DC.

Awad MA, De Jager A (2000) Flavonoid and chlorogenic acid levels in skin of Jonagold and Elstar apples during and after regular ultra-low oxygen storage. Postharvest Biology and Technology
20:15-24

Bhowmick BN, Choudhary BK (1992) Antifungal activity of leaf extracts of medicinal plant Alternaria alternata. Indian Bot Report, 1(2):164-165

Bray HG, Thorpe WV (1954) Analysis of phenolic compounds of interest in metabolism. Methods of Biochemical Analysis, 52:1-27

Changhoo L, Kim S, Ko J, Kim C (2001) Changes in cell wall metabolism of kiwi fruits during low temperature storage by post harvest calcium application. Korean Journal of Horticultural Science and Technology, 42:91-94

Chauhan SK, Thakur KS, Dwivedi SK, Bhanot A (2008) Storage behavior of apple as affected by pre and post harvest treatments of neem based formulations, plant extracts and leaves. Journal of Food Science and Technology 45:484-489

Deshmukh PB, Chavan SR, Rehapurkar DM (1992) A study of insecticidal activity of twenty indigenous plants. Pesticides 16:7-10.

Duque P, Barreiro MG, Arrabaca JD (1999) Respiratory metabolism during cold storage of apple fruit. I. Sucrose metabolism and glycolysis. Physiologia Plantarum 107:14-23.

Ergun M, Satici F (2012) Use of Aloe vera gel as bio-preservative for Granny Smith and Red Chief apples. Journal of Animal and Plant Sciences, 22:363-368.

Erkan M, Pekmezci M, Gubbuk H, Karasahin I (2004) Effects of controlled atmosphere storage on scald development and postharvest physiology of Granny Smith apples. Turkish Journal of Agriculture and Forestry, 28: 43-48.

Golding JB, McGlasson WB, Wyllie SG, Leach DN (2001) Fate of apple peel phenolics during cool storage. Journal of Agricultural and Food Chemistry 49: 
2283-2289.

Gupta N, Jawandha SK, Gill PS (2011). Effect of calcium on cold storage and post-storage quality of peach. Journal of Food Science and Technology 48:225229.

Jinhe B, Baldwin EA, Goodner KL, Mattheis JP, Brecht JK (2005). Response of four apple cultivars to 1-methylcyclopropene treatment and controlled atmosphere storage. HortScience 40:1534-1538

Kaynas K, Sivritepe HO (1995). Effect of precooling treatments on storage quality of mature green tomatoes. Acta Hortic 412:200-209.

Kleeberg H (1996). The Neem Azal conception: Future possibilities of the use of neem in biological and integrated pest management. In: Singh RP, Chavi MS, Raheja RK, New Delhi (eds) Neem and environment. Oxford and $\mathrm{IBH}, \mathrm{New}$ Delhi, pp 875-882.

Leja M, Marezek A, Ben J (2001). Antioxidant properties of two apple cultivars during long-term storage. Food Chemistry 80:303-307.

Levesque PG, Deell JR, Murr DP (2006). Sequential controlled atmosphere storage for 'McIntosh' apples. HortScience 41:1322-1324

Martinelli FM, Busconi F, Camangi C, Fogher A, Stefani, Sebastiani L (2008) Ancient Pomoideae (Malus domestica Borkh. and Pyrus communis L.) cultivars in "Appenino Toscano" (Tuscany, Italy): molecular (SSR) and morphological characterization. Caryologia 61:320-331.

Matthes A, Schmitz-Eiberger M (2009) Polyphenol content and antioxidant capacity of apple fruit: effect of cultivar and storage conditions. Journal of Applied Botany and Food Quality 82:152-157.

Meena HR, Kingsly ARP, Jain RK (2009) Effect of post harvest treatments of shelf life of ber fruits. Indian Journal of Horticulture 66:58-61.

Napolitano A, Cascone A, Graziani G Ferracane R, Scalfi L, Di Vaio C, Ritieni A, Fogliano V (2004) Influence of variety and storage on the polyphenol composition of apple flesh. Journal of Agriculture and. Food Chemistry 52:6526-6531.

Prashant B, Masoodi FA (2009) Effect of various storage conditions on chemical characteristics and processing of peach cv. 'Flordasun'. Journal of Food Science and Technology 46:271-274.

Raj H, Tomar M (2013) Use of aqueous and cow-urine based plant extracts against post harvest diseases of apple. Journal of Mycology and Plant Pathology 43:246-249.

Riveria J (2005) Cutting shape and storage temperature affect overall quality of fresh cut papaya cv. Maradol. Journal of Food Science 70:488-489.

Rombaldi CV, Silva JA, Machado LD, Parussolo A, Kaster LC, Girardi CL, Danieli R (2001) Harvesting stage and cold storage influences on the quality of Chiripa peaches (Prunus persica L.). Ciencia Rural 31:19-25.

Shinde GS, Viradia RR, Patil SA, Kakade DK (2009) Effect of natural plant extracts and wrapping materials on storage behavior of mango (Mangifera indica L.) cv. Kesar. Asian Journal of Horticulture 4:206-210.

Singh UB, Mohammed S (1997) Comparative efficiency of wax emulsion and rice starch on postharvest shelf life of fully ripe guava fruits. Journal of Food Science and Technology 34:519-522.

Tarozzi A, Marchesi A, Cantelli-Forti G, Hrelia P (2004) Cold storage affects antioxidant properties of apples in caco2 cells. Journal of Nutrition 134:11051109.

Tomas-Barberan FA, Espin JC (2001) 
Phenolic compounds and related enzymes a determinants of quality in fruits and vegetables. Journal of the Science of Food and Agriculture 81:853-876.

Tzortzakis NG (2007) Maintaining postharvest quality of fresh produce with volatile compounds. Innovative Food Science and Emerging Technologies 8:111-116.

Valero D, Perez-Vicente A, Martinez-Romero D, Castillo S, Guillen F, SerranoM (2002) Plum storability improved after calcium and heat postharvest treatments: role of polyamines. Journal of Food Science 67:2571-2575.

Van Der Sluis AA, Dekker M, De Jager A, Jongen WMF (2001) Activity and concentration of polyphenolic antioxidants in apple: effect of cultivar, harvest year and storage conditions Journal of Agriculture and Food Chemistry 49:3606-3613.

Wijewardane RMNA, Guleria SPS (2009) Combined effects of pre-cooling, application of natural extracts and packaging on the storage quality of apple (Malus domestica) cv. Royal Delicious. Tropical Agricultural Research 21:10-20.

\section{How to cite this article:}

Neelam Kumari and Sharma, J.N. 2019. Effect of Post Harvest Treatments and Storage Conditions on Physico-Chemical Properties of Starking Delicious Apples. Int.J.Curr.Microbiol.App.Sci. 8(04): 2347-2361. doi: https://doi.org/10.20546/ijcmas.2019.804.274 